quality of the sward. She will bear a calf, give it sufficient milk, and put on weight during the summer. She will, however, give no more milk than is sufficient for a single calf. Any nourishment obtained over and above that requirement will be stored in the body to tide her over the winter. Above all we have here a method whereby a suitable type of cow, one that will produce a good feeding bullock, can rear that calf economically whilst, by combining cattle rearing with sheep rearing, the rough pastures on the hills can be utilized without much expenditure on labour.

This experiment has justified itself and we are going on with it, extending it, and trying out improvements. I am not prepared to say whether it is the best possible system, but it is one method by which a full stock can be maintained on the vast hill areas.

This trial represents a real improvement in the health of hill stocks. During the years before the war so many lambs kept at home in an undernourished condition were in a stunted condition in spring; when they were sent back to the hill, disease took a heavy toll.

Two other experiments were made on the wintering of hoggs. In each case a field was set aside in summer and the grass converted into silage which was fed back to the same ground during the winter. The hoggs did well on grass silage, and when it was stopped each spring they went back to the habit of roaming the hills as usual, contrary to the opinion frequently expressed.

\title{
Discussion
}

Mr. M. Griffith (Welsh Plant Breeding Station, Aberystwyth), opener: To discuss Dr. Russell Greig's paper would take too long. I have enjoyed listening to it. We know too little of the history of agriculture.

As a Welsh member of the Hill Sheep Farming Committee, I think there should be much more interesting interchange of ideas between Scotland and Wales. They have so much in common. Conditions in Wales differ in that we find among farmers and shepherds no prejudice against sending hoggs to the lowlands, but then Welsh hill pastures are more grassy on the whole than those of Scotland. There is room for research on a large scale on these problems.

There is a strong feeling in Wales that pedigree sheep breeders in "improving" sheep have not given enough attention to the question of hardiness. This is important for mountain breeds, especially when the mature stock are wintered at high elevations.

With reference to the improvement of hill pastures, work has been going on in Wales for 11 or 12 years. Some of the pastures laid down about 12 years ago are still going strongly, though some of the better grasses have diminished to a certain extent, their place being taken by Agrostis, but we have been able to keep up the percentage of wild white clover to a very marked degree.

To maintain the sward, cattle must be used for summer grazing. Young cattle bred in the lowlands have been agisted on the hills, and they have made satisfactory progress. Pastures grazed in April and May recover after a short rest. For maximum winter keep they require a longer autumn rest, say from the beginning of August. The stockcarrying capacity of most of the hills which we have tackled, ranging voL. 4, 1946] 
from 1000 to 1300 feet, was something like 1 ewe and 1 lamb in summer, and 1 ewe in winter, to 2 or 3 acres. By cultivating, manuring, and reseeding we have increased the carrying capacity to over 2 ewes per acre in winter, and to 4 ewes with lambs in summer, 75 to 80 per cent. of the lambs being fit to grade by the end of August.

We havo also experimented with the sowing of rye towards the end of June, and sowing grass crops for winter feed. We find that lambs grazed on such crops for one hour daily and then turned back to rough grazings do well. Much more stock can be carried in this way, though. more labour is required.

We are also experimenting with supplementary feeding with various crops in winter to study the effect on both the ewes and lambs when turned back to the open mountain in summer.

Briefly the resultr seem to indicate that the winter feeding of the ewe does not affect the progress of the lamb on the mountain the following summer. The ewes that were in the best condition at the time of lambing reared the best lambs, and these lambs maintained their lead throughout the summer. The effect on the ewes, however, was quite different, and the ewes that were fed on the most concentrated feeding stuffs, such as dried grass or maize, did not maintain their condition when turned back on tho hill, but, on the other hand, the ewes that were fed on improved pastures during the winter maintained their condition far better and also increased in liveweight when turned back on the open mountain.

Dr. A. B. Anderson (Royal Infirmary, Glasgow): If the scheme of grazing cattle on the hills is to be put into operation, will there be enough cattle?

Mr. Martin Jones: There is not much difficulty in increasing cattle stock. Mature cattle, wintered on the hill, require only straw when there is snow, and, so long as the present ploughing policy continues, there will be no shortage of straw. For this kind of wintering the cattle must be hardy. The main thing in regard to the cattle is to have them available at the proper time, that is, fit in spring for summer use.

Mr. Moses Griffith said that pedigree grasses do well on the hill. We have tried commercial, improved and pedigree strains and find the latter more leafy but inclined to start later in the spring. Early spring growth is vital. Strains that start early are best and they can be made to persist provided the management is properly planned.

With reference to the use of young cattle on the hills, our experience is that if they get 4 to 5 acres to run over they do well but, in that case, the plants will not persist since they will run to stem during the summer. 'To get the grass in good condition we find one mature animal per acre best.

Dr. G. Dunlop (West of Scotland College of Agriculture, Auchincruive, Ayr): I am doubtful about statements that hill lands were once fertile and that fertility has been lost largely by being "walked off" in the bones of animals. I should like to hear the speakers' view on the subject.

Dr. J. A. B. Smith (Hannah Dairy Research Institute, Kirkhill, Ayr): At present there is a subsidy on hill sheep. How will the industry compete with Canterbury lamb in peace time? 
Mr. J. A. More (Edinburgh and East of Scotland College of Agriculture, Edinburgh): I am doubtful whether the conditions to which Mr. Martin Jones refers are typical hill sheep farming conditions. Mr. Jones said he can winter cattle on the hill with straw. Compared with his conditions, the Balfour Report on Hill Farming in Scotland (Department of Agriculture for Scotland, 1944) reports that in the best districts there is 1 ewe to 2 acres, in Sutherland 1 ewe to 14 acres, and not much straw or hay. Mr. Jones said the improved hill land carried something like 100 to 150 sheep on 15 acres. I contend that land good enough to do that in winter is not the kind of land that is a problem.

REFERENCE

Department of Agriculture for Scotland (1944). Report of the Committee on Hill Sheep Farming in Scotland. [Cmd. 6494]. Edinburgh: H.M.S.O.

Mr. A. R. Wannop (North of Scotland College of Agriculture, Aberdeen): In reply to Mr. More, the particular farm, with which Mr. Martin Iones dealt, is a fairly typical Highland farm, more so than those in Sutherland. The ground used was formerly a crofting area on medium quality land. There are, of course, farms in the Highlands where there is very little land that could be treated in this way. There are hill sheep farms where not 2 per cent. of the land could be ploughed and devoted to this use, but there are many where it could be done. The difficulty is to persuade the farmers to do it. They admit that hoggs wintered on improved hill pasture are as good as those wintered elsewhere but they still think they should go away.

The cost of ploughing and liming is easily recovered in three years. That of fencing has not been considered in this case because it was a deer fence which is not a just charge against the improvement. Part should be charged to sporting interests.

I agree with Dr. Dunlop about the question of fertility. The importance of the minerals "walked off" is probably not great. Apparently lower fertility is more often a change to less suitable herbage. Up to about 1750 a far greater area of the Highlands was covered with trees. The association of trees with hill grazings is important and has not been given sufficient attention

Mr. Martin Jones: Mr. Wannop has answered most of the questions. With regard to the question of fertility, the spread of white clover has done much to counteract deterioration. In reference to Canterbury lamb, as long as New Zealand can afford to devote good land to sheep, it will be difficult to compete.

Dr. I. Leitch (Imperial Bureau of Animal Nutrition, Bucksburn, Aberdeen): Public opinion should have something to say on that subject. Many would prefer to pay more for home produced hill lamb than for Canterbury lamb. The papers and discussion have shown the need for more intimate contact between research and practical problems. As far as hill sheep are concerned, the question is not of intensive production, to which most of agricultural research in recent years has been devoted, but of finding early maturing grasses and hardy sheep suited to hill conditions, new problems for the plant and animal geneticist.

vor. 4,1946$]$ 
Mr. D. S. Rabagliati (Ministry of Agriculture, 3 St. Margarets Road, Edinburgh): The veterinary profession has not, in the past, taken as much interest as it might in animal nutrition. The study of nutrition is as important as the study of bacteria in the prevention and control of animal diseases.

\section{Pasture and its Dangers to Livestock}

\section{Dr. J. Stewart (Moredun Institute, Gilmerton, Midlothian) \\ The Composition of Pasture}

Ruskin in Modern Painters eulogizes grass in the following words: ". . . judge whether of all the gorgeous flowers that beam in the summer air, and of all strong and goodly trees pleasant to the eye or good for food-stately palm and pine, strong ash and oak, scented citron, burdened vine- there be any so deeply loved, by God so highly graced, as that narrow point of feeble green". Many of you, perhaps, quietly contemplating your well cut lawn on a summer evening might agree with him but those of us who have done any work on those aberrations of diet which cause disease must view grass with rather suspicious eyes because repeatedly we find that the cause of many of the maladies affecting livestock lies in the grass. This being the case it is all the more surprising that our knowledge of the exact chemical composition of grass is so slight and that so little interest is taken in it by agricultural research workers. A good example is the enigma of the Romney Marsh pastures where, on some fields, cattle will not fatten, while on neighbouring fields of apparently similar texture and quality, cattle fatten in a normal fashion. Many research workers have tried to solve this problem but all have failed, although various hypotheses have been advanced.

To the farmer the fattening quality of pasture is his main concern and yet, much more investigation is necessary even of those aspects pertaining to energy or nutritive value of pasture. Wood (1924), summarizing the data then available, declared the starch equivalent of grass to be $50 \mathrm{lb}$., and the digestible protein, $10 \mathrm{lb}$., per $100 \mathrm{lb}$. of dry matter. Only 2 years later Woodman, Blunt and Stewart (1926), in the first of a long series of papers on the nutritive value of pasture, showed that the starch equivalent of young grass was over $70 \mathrm{lb}$., and the digestible protein about $23 \mathrm{lb}$., per $100 \mathrm{lb}$. of dry matter; in other words, young grass was a concentrate comparable in value with linseed cake and, to a grass ration, carbohydrate and not protein should be added as supplement. This was a minor revolution in our thoughts on pasture and was, indeed, the scientific basis on which was based the suggestion of utilizing dried grass, grass cake and grass silage in winter rations. One would have thought that this would be the starting point for much intensive research into the chemical composition of grass, yet we still analyse pasture under the fractions, crude protein, ether extract, crude fibre, total ash and nitrogen free extractives. Surely such appellations must be anathema to a chemist's ingrained exactness. The nature of the crude protein is still obscure despite attempts to determine the amino-acid composition, and still less is known of the other nitrogenous substances. Recently at 